\title{
A cidade como escritura e a paixão da memória*
}

\author{
Ricardo Forster
}

Poderiam ter sido contemporâneos; seus passos poderiam ter se cruzado naquela silenciosa Suíça que os abrigou enquanto a Europa se dessangrava nas tricheiras da Primeira Guerra mundial. Um provinha de comarcas longínquas, de uma paisagem estranha e exótica, quase inimaginável para um refinado expoente da cultura do velho mundo. Porém naquelas margens sulinas - onde as tradições estavam ainda por fundar-se ou fundando-se - suas leituras, todavia, urdiram uma trama cosmopolita, seus olhos esgotaram - em todas as direções - a tradição do Ocidente. A Europa estava nele, em algum momento seu destino teria que inscrever-se em sua geografia. $\mathrm{O}$ outro vinha do centro, de uma terra de inauditas contraposições, a pátria de Goethe e de Wagner, desse território do belo e do monstruoso, da paixão e do espanto; lugar de alquimias, de experimentações assombrosas e carregadas de perigo. Êxtase e decadência da cultura moderna. País de gênios e de exaltados guerreiros ansiosos por imitar seus ilustres antepassados, de eruditos ecumênicos e de ferventes patriotas; uma incógnita de humanismo e de barbárie. Um provinha de um mundo aberto ao novo, excitado por sua exaltada juventude, carente de tradições próprias e ansioso por beber nas fontes da cultura clássica; o outro se sabia antigo, cansado, lançando suas últimas descargas viris antes de esgotar-se definitivamente. $\mathrm{O}$ primeiro via a Europa através de um espelho atemporal, imaginário, que lhe devolvia imagens que já haviam deixado de existir; o segundo escavava na memória de suas tradições para tentar compreender o sentido dessa decadência, o rumo dessa marcha fatigada.

Um chegou à Suíça seguindo os passos de um pai destinado à cegueira - destino que, um dia, também a ele alcançaria -;
*Nota sobre o autor e o texto

Vinte e dois anos atrás, Ricardo Forster nos entregava este manuscrito para um volume que não conseguiria vir a público.

Nele se concentrava numa leitura, absolutamente ensaística, do comum anacronismo de Benjamin e Borges, que converteria ambos os escritores em agudos críticos da lógica do progresso e da modernização. Depois disso Forster publicou, em 1996, Itinerarios de la Modernidad (em co-autoria com Nicolás Casullo e Alejandro Kaufman); El exilio de la palabra. Ensayos en torno a lo judio (1997); Walter Benjamin y el problema del mal (2003); Benjamin. Una introducción (2010); La anomalia argentina (2010); La muerte del héroe (2011); El litigio por la democracia (2011); Nicolás Casullo, semblanza de un intelectual comprometido (2013) e La anomalía kirchnerista. La política, el conflicto y la invención democrática (2013). No ensaio aqui reproduzido, Forster evoca que, em 1955, quando nomeado diretor da Biblioteca Nacional, Borges sentiu que voltava aos bairros antigos e tornava a encontrar-se, nessas ruas demarcatórias e essenciais, com uma certa sacralização da cidade. Recentemente, Ricardo Forster foi designado Secretário 
de Coordenação Estratégica para o Pensamento Nacional, no Ministerio da Cultura da Argentina. A secretaria será provavelmente instalada na Casa da Cultura, recentemente inaugurada na Favela 21 de Barracas, que funciona como sede da Secretaria de Cultura. No centro do centro do centro: o Sul. De Borges a Forster, há um inequívoco percurso para "deter o inexorável transcorrer do tempo". Sirvam estas linhas como desagravo à inútil polêmica gerada pela sua nomeação para um cargo de rótulo infeliz mas tarefa promissora, a de uma memória redentora, tal como a daquela imagem que aparece nas Teses sobre filosofia da História, através da qual Benjamin queria falar da memória dos vencidos. Afinal de contas, embora sem o sentido não haja memória, o importante é não esquecer que, sem a memória, não há espírito.

Em razão do caráter fortemente ensaístico do original de Forster, que não se preocupou em fornecer as referências precisas de textos e livros por ele citados, como tornou-se imperativo nos dias que correm, a tradução que ora apresentamos não segue os padrões editoriais normalmente aplicados aos demais ensaios publicados na outra travessia. Quando o autor indica as páginas de fragmentos citados a partir de edições em castelhano, optamos por manter as edições a que ele refere.

Os editores

**Tradução de Carlos Eduardo Schmidt Capela. ignorantes dos furacões destruidores que ameaçavam o céu europeu. $\mathrm{O}$ outro cruzou a fronteira impulsionado por suas convicções pacifistas, optando pelo erudito contra o patriótico (ao longo de sua dilatada vida o primeiro de nossos viajantes teria a oportunidade de manifestar uma mesma convicção cosmopolita, distante de qualquer veleidade nacionalista). Seus passos, agora o sabemos, poderiam ter se cruzado. Um viveu em Genebra, a cidade de Calvino e de Rousseau, do puritanismo - que o jovem sulista trazia no sangue através de seus antepassados ingleses - e das ideias revolucionárias, uma cidade para ser percorrida por um adolescente faminto de novidades, de saberes escondidos em velhas livrarias, enfebrecido por tudo o que a ele se oferecia: os livros, as línguas e as experimentações dos sentidos. O outro viveu em Berna, cidade calada e bucólica, orgulhosa de seu provincianismo, lugar ideal para aquele que desejava "sair" dos tumultos do presente para mergulhar nas tradições do romantismo alemão.

Genebra foi, para o viajante das terras longínquas, a magia do iniciático, o lugar no qual os sentidos são despertados e a imagem do mundo vai tomando uma forma definida (décadas depois, em sua ancianidade oracular, iria recordar aqueles anos como os mais felizes de sua vida, e aquela cidade como o seu Paraíso pessoal). Para o alemão Berna foi uma cidade de trânsito, um refúgio momentâneo distante dos tumultos contemporâneos; ali aprofundou algumas de suas ideias discutindo apaixonadamente com seu amigo Scholem sobre a linguagem e Kant, sobre o romantismo e o Talmud, sobre literatura, matemáticas e anarquismo; só um tema estava explicitamente proibido: a guerra que troava do outro lado da fronteira. Surpreendente simetria: um vivia a sorte adolescente que é, também, uma forma do ensimesmamento, um sair ao mundo para encontrar-se consigo mesmo e beber, até se embriagar, de todas as fontes e viajar pelas trilhas insondáveis da amizade, do amor e dos livros. O outro, consciente do drama final de uma época histórica, elegeu um cenário apartado, preferiu a tranquilidade do erudito em seu gabinete de trabalho, do viajante intelectual que põe o seu tempo entre parênteses para se deslocar para outros lugares.

Em Genebra Borges ampliou a biblioteca de seu pai (da qual - diria mais tarde - nunca saiu), deixou para trás a casona de Palermo e pôde olhar desde o outro lado das altas cercas, crescendo com independência, elegendo suas próprias leituras, vivendo suas próprias experiências. Genebra foi também para ele o idioma alemão e, sobretudo, foi a cidade onde se encontrou com a obra de Schopenhauer - o filósofo de sua vida. "Se o enigma do universo pode reduzir-se a palavras - diria anos depois -, creio que essas palavras se encontram em suas obras”. Mas a língua de Lutero abriu-lhe um mundo imenso, 
aproximou-o de Heine e da estranha obra de Gustav Meyrink, especialmente seu Golem, permitiu-lhe uma incursão nas antigas tradições germânicas que, logo viria a descobrir, acabariam conduzindo-o até outra de suas paixões: a velha literatura anglo-saxã e escandinava. Mas Genebra foi, acima de tudo, o descobrimento de Walt Whitman, um descobrimento casual, em um sebo, que influiu decisivamente em sua obra poética e que o acompanharia ao longo de sua vida; e, junto ao poeta norte-americano, também se deparou com Rilke. Poderíamos acrescentar outros encontros fundamentais: ali leu com intensidade De Quincey e Carlyle, Flaubert e Baudelaire, Chesterton e Rimbaud, Hugo e Zola. Percorrer velhas livrarias e sebos para tropeçar fortuitamente com algum autor que logo seria essencial em sua vida o aproxima do nosso segundo personagem. Em Berna, Benjamin, acompanhado de Dora, sua esposa, e de Gershom Scholem, seu amigo, continuou sua parábola intelectual, aprofundou suas interrogações sobre o destino da cultura moderna. $\mathrm{Na}$ capital suíça leu Kant com particular intensidade e discutiu largamente com Scholem sobre temas judaicos, enquanto prosseguia suas investigações sobre os românticos alemães, destinadas a se converterem em sua tese de doutorado. Suíça significou para Benjamin um interregno, o distanciar-se de seus país, do militarismo germânico, de uma guerra impiedosa que estava destruindo o melhor do sonho do século XX. Mas também lhe permitiu, através de seus debates com Scholem, aprofundar-se em suas inquietudes teológicas, em suas indagações linguísticas e naquilo que logo seriam seus vagabundeios pela proto-história da modernidade.

Para Borges Genebra foi, e isso não deixa de ser surpreendente, a possibilidade de encarar de outro modo seu lugar de procedência, de percorrer com a memória a cidade distante, essa Buenos Aires que iria adquirindo traços míticos. A distância lhe abriu um mundo inesperado; descobriu que não havia incompatibilidade entre essa cultura que estava adquirindo apressadamente, em Genebra, e esse mundo semi-bárbaro que havia conhecido ou entrevisto na Palermo de sua infância. Suíça foi, para o jovem Borges, o descobrimento fascinante do cosmopolitismo da cultura, ali pôde entremesclar livros e autores; Lugones com Whitman, Hernández com De Quincey, Sarmiento com Verlaine. A incomensurável imensidão do pampa encontrou um lugar nas labirínticas ruelas da velha Genebra, a ponto de estas vivências dissímeis, passados os anos de formação, terem alcançado perfeita conjunção em sua obra literária.

Sua aprendizagem, antes de chegar à Europa, circunscreveu-se à biblioteca de seu pai que, para o menino que era então, era vasta como o universo, labiríntica como o palácio de Minos e maravilhosa como As mil e uma noites - cujas ficções inolvidáveis leu naqueles anos felizes. Nela Borges se converteu 
num verdadeiro leitor, vivendo - como só uma criança pode fazer - a plena realidade da literatura. Genebra foi outra coisa (embora, no decorrer de sua vida extensa, nunca tenha perdido essa paixão infantil pela leitura desinteressada, por essa biblioteca "da qual nunca saiu" e que fundou, de uma vez e para sempre, sua imagem do mundo; Borges escreveria, mais adiante, que viveu preso em seus "extraordinários sortilégios”). $\mathrm{Na}$ cidade de Calvino pôde vagar solitário e livre, com desprendimento, percorrendo quadra atrás de quadra, vasculhando velhas livrarias que o transportavam, através de seus encontros, até todas as regiões da literatura e do pensamento. Ali pôde literalmente se perder, praticando a arte de vagabundear que é a única que nos permite - como diria Benjamin - conhecer a fundo uma cidade. Em Genebra Borges ainda cultivou a amizade e descobriu suas bondades, bem como experimentou pela primeira vez as necessidades do corpo. A cidade e os livros educaram o jovem portenho, aperfeiçoaram o que já tinha ido adquirindo na biblioteca de Palermo. "À parte as escolas fui educado por uma biblioteca - a de meu pai -; em que pese às vicissitudes do tempo e das geografias, creio não ter lido em vão aqueles queridos volumes” (Obras Completas, p. 236).

Para Borges a Europa significou, como já o mencionamos, um duplo descobrimento: o do cosmopolitismo cultural e o da liberdade adolescente, por um lado, e, por outro, e de não menor importância, a profunda percepção de Buenos Aires como memória ativada no presente. No poema "Arrabalde", que integra Fervor de Buenos Aires (o primeiro livro que escreveu depois de regressar da Europa), Borges expressa de modo paradigmático o que tentamos assinalar:

Esta cidade que acreditei ser meu passado

é meu futuro, meu presente;

os anos que vivi na Europa são ilusórios, eu estava sempre (e estarei) em Buenos Aires.

A experiência europeia - primeiro Genebra e depois Espanha - reforça os laços com sua cidade natal, oferece-lhe uma percepção mais funda do cruzamento entre sua escritura e Buenos Aires, que vai paulatinamente se convertendo no início e no destino final de todas suas peregrinações. $\mathrm{O}$ único real, junto com os livros lidos ou por ler, são as ruas de Buenos Aires, Palermo, o sul, Adrogué, o hotel "Las delicias”, um pátio profundo, uma caminhada noturna com algum amigo (recuperando suas saídas genebrinas e, logo depois, nas cidades espanholas), uma conversa em um bar do Once com Macedonio Fernández. Cidade-refúgio, espaço para uma errância lúdica, cobertura ontológica, pátria contra os exílios. A Europa, ao contrário, é "ilusória", uma parada fugaz, uma visão relampe- 
jante e iluminadora que ao longo dos anos acabaria entrelaçada com sua comarca sulina. Nestes anos juvenis Borges ainda não tem tempo para sentir a nostalgia de uma juventude que escapa de suas mãos como a areia do mar, todo o seu fervor está posto em Buenos Aires. Mas no final de sua vida irá se recordar, com essa nostalgia de que carecia nos anos vinte, uma nostalgia nascida do passar do tempo e da vida que lentamente se esvai, de Genebra, sua "outra” cidade, a da adolescência, a da amizade, a antiga e venerável cidade de Calvino, aquela que volta através da lucidez implacável da recordação. É ali, então, que se dá o cruzamento entre Buenos Aires - a cidade eterna - e Genebra - a da felicidade.

A escritura de Borges, assim como a de Walter Benjamin, assemelha-se a seu caminhar pela cidade, com seu ritmo, com a limpeza do acaso, das ruas que se entrelaçam em um labirinto cuja saída já está descortinada. A narrativa de Borges se sustenta (em um de seus pilares) na cidade e em sua experiência caminhante.

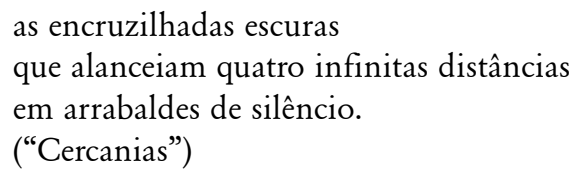

Estes versos talvez encerrem a visão borgeana da cidade. Metáfora (que também encontraremos em Benjamin) que reúne "encruzilhadas" e "infinitas distâncias"; visão de um impossível acabamento, de uma vagância por "arrabaldes de silêncio" que prolongam por todos os lados os tentáculos da cidade. Como caminhar por ela? Para onde ir? Benjamin dirá que só conhecemos de fato uma cidade quando aprendemos a nela nos perder, quando nela penetramos e nos deixamos atravessar pelos quatro pontos cardeais (Borges, em "A morte e a bússola”, constrói uma imagem da cidade solidária com o olhar benjaminiano). A metrópole como um manto velado que o caminhante, com infinita paciência, pode ir descortinando. Mas também a cidade como memória, quase como uma experiência anacronizante que comove o andar distraído do passante que busca, ao seu redor, aquilo que já deixou de existir, aquilo que se perdeu entre as dobras das recordações. "A imagem que temos da cidade - escreve Borges em "O indigno" - sempre é algo anacrônica. O café degenerou em bar; o saguão, que nos deixava entrever os pátios e as videiras, é agora um obscuro corredor com um elevador no fundo". Quem se perdeu sabiamente em uma cidade é capaz de romper a monotonia da sucessão temporal, de escapar dessa forma mefistofélica de destruição da memória que é o progresso; mas é ainda possível perceber de outro modo o deslocamento do presente para o futuro, porque 
“... assim como há plantas das quais se diz que possuem o dom de fazer ver o futuro, existem também lugares que têm a mesma faculdade. Em sua maior parte são lugares abandonados, como copas de árvores que estão junto aos muros, ruelas sem saída, jardins diante das casas, onde jamais pessoa alguma se detém. Nesses lugares parece ter passado tudo o que ainda nos espera" (Infancia en Berlin). Hieróglifo que o caminhante procura decifrar, espaço onde se mesclam realidade e ficção e onde a escritura vai encontrando seu ritmo, seus temas, tomando conta das obscuridades que a paisagem urbana encerra, de suas infinitas trilhas e de suas fantasmagóricas silhuetas que a atravessam confusamente, em múltiplas direções. Talvez daí nasça essa inaudita necessidade de perder-se em ruas labirínticas que podem esconder surpreendentes segredos, ou revelar-nos a trama escorregadia do futuro, não nas formas esplendorosas que adquire nos monumentos exemplares do presente, mas em suas ruínas, em seus rincões esquecidos e em seus restos, ali onde o "moderno" volta para nós seu outro rosto. Se a cidade há de ser decifrada, do mesmo modo a literatura - como com acerto escreve Davi Arrigucci - é para Borges "uma arte do deciframento", impulsionada por uma inacabável "curiosidade intelectual" que se assemelha à atitude inquisitiva diante dos livros e do universo. Para Borges, caminhar pela cidade pressupõe reencontrar-se com o passado, viajar até esses penumbrosos e esquecidos rincões da memória, já que, para o autor de "O Aleph", "[P]ossuímos o que perdemos; acaso é esse o encanto que tem o passado. O presente carece desse encanto. Eu creio que o passado é uma das formas mais belas do perdido" (em R. Alifano, Borges, biografia verbal, p. 71). Sua anacrônica maneira de caminhar por Buenos Aires simboliza com extraordinária exemplaridade o sentimento borgeano do passado como "uma das formas mais belas do perdido". Em Sete noites, Borges se detém, com a morosidade do conversador infatigável, em suas recordações, desanda, através das palavras, esse sentimento de uma nostalgia vivida como sonho (também Benjamin amparou sua escritura, e sua visão do presente, nessa peculiar sensibilidade que somente a nostalgia fecunda). "Se eu penso em Buenos Aires - comenta o velho Borges -, penso na Buenos Aires que conheci quando criança: de casas baixas, com pátios, com saguões, com tanques com uma tartaruga, com janelas de veneziana, e essa Buenos Aires era antes toda Buenos Aires. Agora só se conserva em bairros do sul" (Obras completas, p. 279). Literatura urbana, atravessada inextricavelmente pelo labirinto de ruas que povoam seus sonhos, de um tempo que rompeu sua linearidade e que entrelaça festivamente o longínquo do vivido com a urgência do atual; ensaísmo submetido ao vai-e-vem surpreendente e inesperado do caminhante que, com passo descompassado, percorre infatigável a metrópole, 
deixando-se levar por seu ritmo, mesclando com sabedoria acaso e certeza. Borges e Benjamin, duas escrituras da cidade e na cidade, amparadas por seus encontros e seus extravios, ansiosas pela novidade de cada esquina e pela repetição balsâmica do conhecido. Cidade da infância, aventura das tardes de verão, magnífica e aterradora; cidade da adolescência, erótica vivência da infinitude, do descobrimento, da selvagem liberdade; cidade que lentamente vai se convertendo em recordação, âmbito trabalhado pela memória, espanto pelo ontem impiedosamente ido. Metáfora do universo, cenário inabarcável da vida.

Borges vê Buenos Aires com olhos antigos; sua visão da cidade não é contemporânea, uma experiência concreta do presente, mas remonta a sua infância e ao que viram e viveram seus antepassados (quiçá a cegueira - o destino dos Borges significou, como a Funes a prostração, a recorrência, no escritor, da memória como fonte de suas narrações). Borges regressa uma e outra vez à Buenos Aires de Rosas, a cidade baixa, com pátios e saguões, uma cidade ainda provinciana que não deixou de ser uma grande aldeia, com suas periferias e suas margens abertas à imensidade da planície e do deserto. Borges nos fala do Sul como se fosse o último resto dessa cidade mítica desaparecida. Escutemos suas palavras: "E a alegria de voltar ao bairro de Monserrat, no Sul. Para todos os portenhos o Sul é, de modo secreto, o centro secreto de Buenos Aires. Não o outro centro, um pouco ostentoso, que mostramos aos turistas [...]. O Sul viria a ser o modesto centro secreto de Buenos Aires” (Obras completas, p. 279). E sua escritura persegue essas formas fantasmais que os olhos enceguecidos seguem vislumbrando nas ruas de uma cidade metamorfoseada. Borges é a memória literária de uma Buenos Aires desvanecida na vaporosa recordação de sua mãe. Cidade da memória que reinstala no presente o labirinto mágico das origens. Seu destino de escritor, para Borges, está inexcedivelmente entretecido com essa experiência anacronizante de Buenos Aires. O autor de Ficções relata que deve à irmã, Norah, sua imagem imperecível da cidade do Prata, pois "ela descobriu algo que eu não havia descoberto. Ela descobriu que Buenos Aires era uma cidade muito extensa, de casas baixas, com pátios, que era uma cidade horizontal (agora é vertical). Ela me disse: 'Que admirável! Esta cidade, tão longa e tão plana, e no entanto fica bem'. E daí saiu Fervor de Buenos Aires, toda a minha literatura, digamos...” (Borges el memorioso, conversas de J.L. Borges 
com A. Carrizo, p. 74). Em 1955, quando nomeado diretor da Biblioteca Nacional, Borges sentiu que voltava aos bairros dos seus velhos, que voltava a encontrar-se nessas ruas demarcatórias e essenciais. Há nele algo como uma sacralização da cidade que se expressa com clareza em seus primeiros livros. Ao caminhar pela cidade e ao descrever literariamente essas experiências e essas lembranças de família, Borges se afasta de toda exaltação da modernização, porque não lhe interessa a cidade que emerge da picareta modernizadora.

Bairros escuros e baixos, casas com pátio, saguão e tanques, território de personagens esquecidos pela história, ruas tortuosas, essa é a cidade do escritor, é aquela que sua memória percorre, minuciosamente, entretecendo suas próprias recordações com os relatos de sua mãe e de sua avó. Para Borges Buenos Aires continua sendo a mesma de sua infância em Palermo, ainda que agora ele se refugie no Sul, o último baluarte já derrotado. Importa a sensibilidade, as imagens da meninice, o que ficou gravado na retina, o que escutou dizer quase em voz baixa pelos velhos daquele tempo mítico e monstruoso do Tirano; importa a fluência caprichosa da memória, não o catálogo minucioso das transformações urbanas. Quando Borges caminha por Buenos Aires ele sai do presente, escapa desse gigante inabarcável e estranho que não lhe pertence, e se deixa convocar por essas imagens distantes de um passado que impulsiona sua escritura. A nós importa segui-lo nessa errância que desloca o presente e que abre uma brecha para outro tempo e para outro lugar. Benjamin, em suas vastas caminhadas parisienses, quando conjugava suas horas diurnas na Bibliothèque Nacionale com o extravio noturno, fez algo muito parecido ao que foi feito por Borges: buscava nos restos, nos desperdícios do dia, a cidade do século XIX. Não é demais assinalar que os dois vivem suas cidades - Buenos Aires e Paris - desde a ótica do século XIX.

Paris é, para Benjamin, Baudelaire, o flâneur, os bulevares abertos pela sede modernizadora do barão Haussmann, a exposição mundial, as arcadas de aço e vidro, os últimos restos das ruelas medievais, a cidades das barricadas e de Blanqui. Acompanhado do francês de Proust, Benjamin perscrutou minuciosamente as ruas parisienses, deixou-se levar por outro cenário, captou os sons de uma cidade já desaparecida; também ele, como Borges, viveu outra cidade, caminhou por outras ruas e se deteve a esquadrinhar os objetos que lhe remetiam a esse mundo do século XIX, fenecido em consequência da extenuante realização de seus próprios ideais de progresso. Benjamin percorreu a cidade de Baudelaire para entender o seu próprio tempo; fez a arqueologia do século XIX, escavou as origens do moderno para penetrar nos segredos de uma época destinada ao ocaso. Ele descobriu duplamente Paris: atravessou-a ao aca- 
so e labirinticamente em noites intermináveis; às vezes só, outras guiado pelos passos perspicazes de alguma prostituta, mas dela também se apropriou através de seu passado, de sua agônica memória escondida entre os milhares de documentos guardados na Bibliothèque Nacionale. Benjamin descobriu Paris com seus passos descompassados e com os livros, uma maneira sublime de penetrar nos mistérios de qualquer cidade. Sorte do caminhante que ama perder-se para poder encontrar e sorte do leitor que sai à caça de algum fragmento especialmente feliz. Quanto se parecem Borges e Benjamin! Paris e Buenos Aires, sua paixão de caminhantes, de passeadores da memória, sua infatigável devoção aos livros e às bibliotecas, suas indagações constantes sobre os misteriosos meandros da linguagem, o alvoroço cotidiano e bendito da escritura, a cegueira e a extrema miopia, sua lucidez termidoriana, seu pendor ao minúsculo, sua paixão comum pela literatura infantil. Os dois percorreram com entusiasmo os labirintos da língua, sentiram o alento de Deus na sonoridade das palavras.

Nunca se leram (Borges porventura pode ter se deparado com algum texto de Benjamin, que alguns de seus amigos da editorial Sur seguramente conheciam), porém isso não parece ser importante. São tantos os pontos em comum que fica a impressão de que se leram atentamente, que se conheceram em profundidade, compartilhando prolongadas caminhadas por suas cidades, conversando até o amanhecer sobre seus livros amados, sobre a Cabala, que ambos conheceram por Scholem, sobre os segredos que esconde toda biblioteca, talvez sobre Shakespeare e sobre os barrocos alemães, seguramente sobre os simbolistas franceses e sobre livros de infância, sem esquecer sua especial inclinação pelos romances policiais e pelo cinema. Benjamin teria se sentido profundamente comovido por Deutsches Requiem ou por O Aleph, Borges teria lido fascinado as Teses de filosofia da história ou o ensaio sobre Kafka (como passar por alto que os dois amaram com intensidade o escritor de Praga, e que ambos imaginaram que o acompanhavam em uma longa caminhada pelo gueto, tratando de seguir a pista do Golem?).

Borges encontrou a universalidade desde os subúrbios; habitando teimosamente as fronteiras do mundo lá descobriu o cosmopolitismo da cultura. Benjamin viveu escapando do centro, afirmando-se em seus umbrais, escrevendo postumamente, desconhecido e solitário, último representante de uma época e de uma cultura extenuadas e lançadas no precipício da barbárie. Borges enxergou através das lentes longínquas de Buenos Aires os segredos das línguas do Ocidente; Benjamin observou nos escombros da modernidade sua própria finitude. Borges morreu na cidade onde transcorreu sua adolescência feliz e iniciática, quis tomar distância de Buenos Aires, afas- 
tar-se de seus fantasmas e de seus pesadelos, do passado que golpeava infatigável a memória do ancião. Borges viveu uma vida extensa, às vezes feliz, outras infeliz; sua existência foi, de qualquer maneira, determinada pela sina da literatura, abarcada pelos volumes da biblioteca de Palermo nos arrabaldes de Buenos Aires onde, como Francisco Laprida, se encontrou com seu destino sul-americano. Borges caminhou lentamente até a morte, tomou a si o seu tempo, deteve-se em cada dobra do caminho, aguardou-a com calma, às vezes desejou apressá-la, mas em geral esperou-a sem excitações, como se fosse uma antiga conhecida, sentindo com alívio o outono de seus anos, essa sensação de entrar pausadamente, e com os olhos abertos, na eternidade. Benjamin viveu acossado por sua fidelidade de escritor destemperado, incansável em sua persistente extraterritorialidade; quiçá se soubesse póstumo, por isso tomou providências, obsessivamente, para que seu amigo Gershom Scholem mantivesse com cuidado, e atualizadas, cópias de todos seus trabalhos. Ele sabia que algum dia, em outra encruzilhada cultural, alguém leria seus escritos; outros leitores, não seus contemporâneos, prestariam atenção a suas ideias (Scholem e Adorno se ocupariam de resguardar a memória do amigo, de editar seus ensaios, de dar-lhe a conhecer ao público). Benjamin tinha consciência de ser um dos últimos expoentes de um mundo cultural no momento de seu crepúsculo. Em todo caso, e esta talvez seja uma profunda diferença com relação a Borges, Benjamin não via diante dele uma vida prolongada; a velhice não estava em seus planos de fugitivo e de intelectual desenraizado. Como em um conto de Borges, o destino o esperava em uma fronteira.

Ambos "haviam se demorado nos gozos da memória", suas obras foram talhadas pacientemente com o material extraído das recordações, em um jogo interminável onde a tradição iluminava a novidade. Borges escreveu em forma de poema esta certeza:

Somente uma coisa não há. É o esquecimento.

Deus, que salva o metal, salva a escória

E cifra em sua profética memória

As luas que serão e as que terão sido.

(“Everness")

Viajantes de zonas tingidas pelo cinza do esquecimento, exegetas de pergaminhosos manuscritos decompostos pela passagem vertiginosa do tempo. As cidades amadas foram para eles um hieróglifo a decifrar, um labirinto que deveria ser percorrido insubornavelmente, uma série dispersa de infinitos rastros deixados pelos fundos obscuros da memória. 
Borges sempre foi fascinado por esses personagens marginais, figuras brumosas de uma época pretérita que representavam, para o escritor, um mundo de valores volatilizado, sepultado sob os escombros da antiga cidade que dava lugar à urbe moderna. O marginal preservava a memória de outro tempo, e Borges, através desses personagens dos arrabaldes, tentou seguir as pistas deixadas por uma cidade que se esfumava, que vertiginosamente se transformava em um monstro impiedoso, em uma massa informe que se estendia por todos os confins, borrando os rastros da memória.

Benjamin perseguiu nas noites parisienses o sabor e o odor de outra cidade, de outra idade; buscou nos olhos abismais das prostitutas as senhas da identidade, a contra-senha para penetrar nessa outra cidade, que despertava quando os honestos cidadãos se retiravam ao interior protegido de seus lares burgueses. Livros e prostitutas, uma combinação estranha, uma alquimia original para penetrar no mistério da metrópole moderna. O comércio da noite, a laboriosidade do trapeiro e o olhar que fecunda no outro o desejo que se oculta na fugaz figura da hetaira noturna. Uma aprendizagem da cidade desde seus bastidores, atravessando seus fundos nebulosos, suas zonas proibidas, perdendo-se nos meandros da intriga e do desejo. Cidade vermelha, espreitante, erótica, anti-burguesa e antiga, essencialmente antiga e pré-moderna, como o fio nunca cortado de uma memória em perpétua metamorfose. Ali o berlinense aprendeu a decifrar, no brilho ostentoso do presente, os signos da decadência, descobriu o esgotamento das promessas do século XIX investigando seus restos como alegorias de um sofrimento por vir. Viajando até o passado soube deslizar através das gretas de uma modernidade que, sem o saber, penetrava na noite de sua história, no tempo de seu ocaso. Benjamin, o caminhante, buscava o impossível de achar, tratava de encontrar as outras cidades, as outras épocas, as outras vozes no tecido urdido pela metrópole contemporânea. Borges, caminhando rumo à cegueira, continuou vendo sempre a mesma cidade abrumada pelo passar dos anos e pelo frenesi do progresso. Benjamin, porventura mais pretensioso, tratou de descobrir a Paris do século XIX em sua dupla deriva: das ruelas noturnas dos bairros desprezados pela decência burguesa e da massa de materiais empilhados e sepultados na Bibliothèque Nacionale. Borges manteve em sua memória a cidade da infância, aquela relatada por seus pais e avós; Benjamin se apropriou de Paris através de sua literatura e de um paciente exercício arqueológico. Trajetórias distintas porém simétricas; os dois viveram o presente como uma fuga literária em direção ao passado, ou, talvez melhor, evocaram no presente os fantasmas do passado, viram a decadência em meio ao esplendor. Viveram a história como escritura, caminharam pela cidade 
como se esta fosse uma obra estética, e a descreveram como metáfora da sociedade.

“Somente um coisa não há. É o esquecimento". Tema essencial que atravessa como um fio delgado porém contínuo a obra borgeana e que constituiu um dos principais eixos reflexivos da escritura de Benjamin. O esquecimento e a memória sempre vão juntos, necessitam um do outro ali onde mais de opõem; a vastidão do tempo tece caprichosamente a tela onde estas duas figuras disputam uma impossível supremacia.

A memória chega a ser a tão temida imortabilidade, o terrível cansaço das obscuras noites de insônia, o vasto horror de recordar para sempre o ontem, o suplício do sofrimento reiterado, ou a melancólica doçura da infância que retorna em meio à maturidade impiedosa. Mas a memória é também pertencimento, supõe uma trama complexa na qual se juntam a esperança e a dor acumuladas por todas as gerações que morderam o pó da derrota; a memória carrega a pesada carga de uma promessa de restituição, é o feroz combate que os homens empreendem contra os fantasmas acariciadores do esquecimento, é a conjunção de gerações dispersas que se perderam no redemoinho da história.

O esquecimento é morte, é o desejo do nada, desejo exemplar e atroz, final de toda saga, silêncio definitivo da palavra que foi pronunciada para perpetuar o tempo do homem e que se encontra sufocada pela mudez do passado, é o vazio na sonoridade da fala.

Borges titubeia inquieto entre a memória e o esquecimento; algumas vezes extasia-se com o vigor heroico dos antepassados, de antigos guerreiros sepultados pela poeira da história, que o poeta tenta recuperar da noite dos tempos. Guerreiros vikings, guerreiros da independência americana e das lutas civis que o poeta sonha na convergência tumultuada de seu sangue. Passos que buscam resgatar essa outra cidade que se espalha em direção ao Sul, onde o caminhante procura deter o inexorável transcorrer do tempo. Essa memória guardada na escritura de Borges é redentora, a exemplo daquela imagem que aparece nas Teses de filosofia da História, através da qual Benjamin nos fala da memória enquanto reabilitadora das gerações vencidas.

A memória, e isso Borges e Benjamin o sabem, é sempre dolorosa e traz as marcas inapagáveis do punitivo, inclusive onde nos oferece as imagens de uma felicidade passada. É pre- 
cisamente ali que a pontada da dor se revela mais intolerável. $\mathrm{O}$ esquecimento, ao contrário, tece seu manto protetor e cura as feridas; mas também para nós insinua o silêncio ameaçador e cega nossos olhos, já incapazes de olhar para trás. "Jamais poderemos resgatar tudo o que esquecemos - escreve Benjamin. Talvez seja melhor assim. O choque resultante de sua recuperação seria tão destruidor que instantaneamente deveríamos deixar de compreender nossa nostalgia. De outra maneira a compreendemos, e tanto melhor, quanto mais profundamente jaz em nós o esquecido. Do mesmo modo que a palavra perdida, que acaba de fugir de nossos lábios, nos infundiria a eloquência de Demóstenes, assim o esquecido parece pesar por toda a vida vivida que nos promete [...]. Quiçá seja a mescla com a poeira de nossas moradas derrubadas o que constitui o segredo para aquele que sobrevive" (Infancia en Berlín, p. 76). Esquecemos para recordar; suportamos a dureza da marcha porque somos capazes de esquecer o sofrimento das gerações passadas. Existem sempre, contudo, aqueles que recordam, os que insistem, ainda que sem o querer, em exercitar o difícil movimento da memória que vai tomando forma através das filigranas do escritor. Borges, o memorioso, pertence a essa saga de homens atravessados por uma escritura destinada a voltar para trás, a deter-se naquelas zonas brumosas que a maioria dos homens prefere negligenciar. Borges se sente assaltado pelo fantasmas de outrora, é um poeta que se deixa dizer pelos sons de um passado que rasga o presente. Seus versos falam por ele:

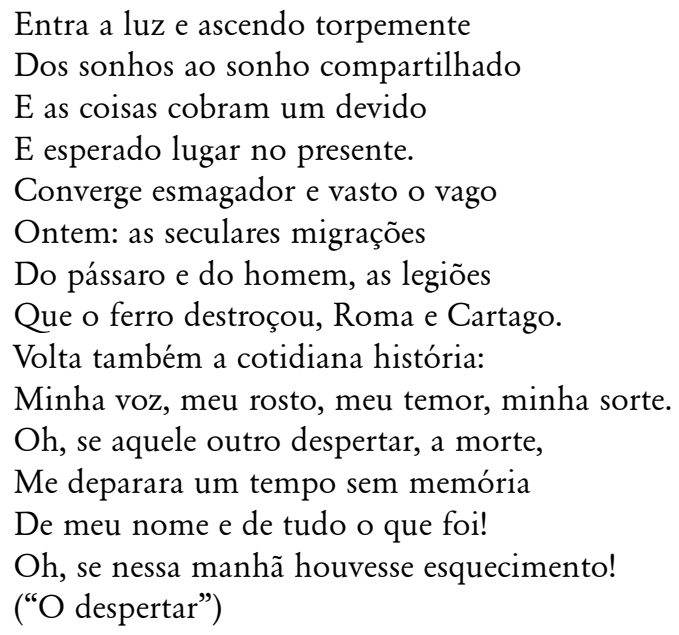

Despertar e esquecer (que para o poeta significa o trânsito até a morte). Que se apaguem as imagens sombrias de outrora, as que assaltam impiedosamente o sonho do poeta que, no entanto, persegue através do itinerário em zig-zag de sua escritura a plenitude do passado, talvez sua própria perdurabilidade, suas inconfessadas aspirações de alquimista. 
1. "sem o sentido não há memória e sem a memória não há espírito" (N.T.).
Peço a meus deuses ou à suma do Tempo

Que meus dias mereçam o esquecimento,

Que meu nome seja Ninguém como o de Ulisses,

Mas que algum verso perdure

$\mathrm{Na}$ noite propícia à memória

Ou nas manhãs dos homens.

(“A um poeta saxão")

A pena de Borges cruza os caminhos e mescla os sentidos; os dois rios - o do Lete e o da Aleteia - convergem em um mesmo estuário. Que permaneça a palavra, aquela que foi executada em um momento de inspiração bendita; uma palavra para acompanhar a noite dos homens ou, mais intenso ainda, suas manhãs, quando o esquecimento ameaça apagar tudo e todos. Borges se detém em suas lembranças, persegue ao longo de sua obra aquelas imagens que se detiveram para sempre em sua memória: Palermo, a biblioteca de seu pai, os verões em Adrogué, suas leituras infantis, Genebra, as conversas com Macedonio Fernández, o saxão, a poesia de Whitman; mas talvez intua, também, a existência de uma forma perversa do esquecimento, fecundada em uma época que fez o culto da fugacidade, que sacralizou a novidade e que vive fascinanda pelo esplendor agonizante da modernidade, da técnica que oprime o cotidiano dos homens. Borges luta contra essa forma de esquecimento, diante dela entrincheira-se na memória, retorna uma e outra vez a suas lembranças, a seus livros e a sua biblioteca. Também se entrincheira na escritura como refúgio do erudito diante da investida da neo-barbárie tecnológica.

Sua viagem ao anglo-saxão e às sagas islandesas, sua obsessão por uma cidade fantasmagórica e evaporada no tempo, a presença permanente de suas leituras juvenis expressam o desgosto borgeano por uma época impiedosa e vazia, por um tempo sem guerreiros nem cabalistas, sem livros sagrados, por uma época que vai ficando sem poetas. Por isso é importante reler o passado, submergir-se nele, reconhecendo seus rastros no presente. Em Borges, diferentemente de Stephen Dedalus, a história não é apenas pesadelo, o horror da recorrência da qual é preciso tratar de escapar. O seu deter-se na memória implica conjugar as duas dimensões, a do pesadelo e a da redenção. Porque em "épocas de indigência técnica - escreve Raul Antelo -, em que a dificuldade para estruturar o novo nos remete à complexidade de gerar compartimentos convencionais, torna-se prioritária essa aventura da memória cuja lição, lembrando Voltaire, é a de que 'sans le sens il n'y a pas de mémoire et sans la mémoire, il n'a pas de esprit'. ${ }^{1}$ Se a história é memória, a ficção é memória e esquecimento, ir e vir da escritura, evasão do presente e presença do evasivo”. Estas palavras cabem a Borges precisamente porque sua escritura internou esse jogo no qual a história se transforma em ficção, e a ficção em 
história. A literatura borgeana leva em conta os segredos - às vezes inescrutáveis - da marcha casual da história do mundo, e, na infinidade de temas que parece abordar inesgotavelmente subjazem, no entanto, as preocupações de sempre: o tempo, a imagem monstruosamente duplicada no espelho, seus sonhos de tigres de cor amarela, o heroísmo de personagens esquecidos, as indagações voluptuosas da origem arcana e misteriosa da linguagem, suas impressões de caminhante infatigável pelas cidades valiosas da memória, a obsessão do labirinto e a biblioteca como cosmogonia do universo. Uma escritura, enfim, que experimenta, sem pretender se constituir em estilo vanguardista, e que somente deposita sua confiança no feliz encontro de forma e conteúdo, na sonoridade exuberante de algum poema imortal.

Tais recorrências justificam a escritura borgeana, outorgam a ela um andaime, a beleza de uma arquitetura complexa e simples ao mesmo tempo. "Aí estão meus hábitos tais e quais: Buenos Aires, o culto dos mais velhos, a germanística, a contradição do tempo que passa e da identidade que perdura, meu estupor de que o tempo, nossa substância, possa ser compartilhado" ("Prólogo" a O outro, o mesmo). O aparente barroquismo que parece atravessar a obra de Borges em realidade esconde suas recorrências, a fidelidade a "seus hábitos", a permanência de suas conjecturas de sempre. Ele construiu com astúcia a sua obra, como se fosse ela um labirinto feito de mil tradições e repleto de leituras, e, entretanto, esse labirinto tem, a exemplo de toda construção complexa, sua própria lógica, a coerência de seus enganos e a sabedoria do estrategista que tenta confundir o adversário. Ler Borges é tratar de descobrir a lógica oculta que torna possível escapar com sucesso da armadilha do Minotauro. Ou, quem sabe, uma das intenções secretas de Borges não teria sido a de nos fazer crer que conseguimos descobrir seus códigos? É possível, contudo vale bem a pena arriscar-se a ser enganado. Em seu poema "Ariosto e os árabes” Borges metaforiza sua própria obra:

Ninguém pode escrever um livro. Para

Que um livro seja verdadeiramente

São requeridos a aurora e o poente,

Séculos, armas e o mar que une e separa.

Uma estética em que se cruzam o mistério e a reflexão filosófica. Uma estética na qual o saber do erudito, daquele que atravessou com ardor e paixão certas tradições, confunde-se harmoniosamente com certo misticismo que emerge da escritura borgeana. Toda essa maravilhosa alquimia (onde se entrelaçam a memória, o amor por Buenos Aires, a paixão pelas etimologias, a surpreendente erudição nascida de ter esgotado os 
livros e, sobretudo, as enciclopédias) se encontra encerrada em "Outro poema dos dons", no qual Borges atravessa belamente todos seus amores, suas ilusões, suas paixões:

\author{
Graças quero dar ao divino \\ Labirinto dos efeitos e das causas \\ Pela diversidade das criaturas \\ Que formam esse singular universo.
}

No poema está a obra, está a razão e está Swedenborg, nele se recorda As mil e uma noites e A Divina Comédia; em seus versos renova-se o fervor pelos Vikings e pela poesia de Verlaine. Borges recupera, não sem ironia, Sêneca e Luciano, "de Córdoba / que antes do espanhol escreveram / toda a literatura espanhola”. E o xadrez com sua infinita geometria e sua exata conjunção de razão e acaso. Todo o mundo heterogêneo de Borges desfila pelas estrofes do poema; deter-se nele é penetrar em sua história, sua biografia, perceber a exuberância e a fragilidade das recordações.

Borges modela o material de sua memória, converte-o em ficção. Benjamin tenta penetrar no moderno levando em conta, precisamente, a função agônica que cabe ao passado na experiência cotidiana da sociedade burguesa. Ele é, a seu modo, um batalhador contra o esquecimento, um arqueólogo que com infinita paciência se detém no exame dos restos frágeis, dos despojos que "a deusa indústria" lança todos os dias e que os homens são incapazes de perceber como expressão brutalizada de sua sociedade. Viver no “atual” significa - para o homem moderno - anestesiar sua memória, tornar opacas suas recordações e deixar de perceber, na feroz fugacidade da moda, a eterna repetição do mesmo. "Nós nos fizemos pobres - escreve Benjamin -. Fomos entregando pouco a pouco a herança da humanidade, com frequência tendo de deixá-la na casa de penhores, por cem vezes menos seu valor, para que nos adiantem a pequena quantia do 'atual"” ("Experiencia y Pobreza", p. 173). Esse fascínio pelo 'atual' corre paralelo à displicência contemporânea com relação à "herança da humanidade”, uma sorte de alucinada corrida rumo a um futuro intangível. Benjamin, através de sua escritura, tenta evitar esta tendência de época, esta obnubilada inclinação pela exaltação do "novo".

Há uma ideia benjaminiana, herdeira do espírito judaico, que é importante assinalar neste contexto: cada linha escrita era "uma vitória arrancada às potências das trevas, de tão incerto" que aparecia o futuro aos olhos da tradição de que Benjamin faz parte. Estas palavras foram escritas poucos meses antes de seu suicídio, nessa fronteira cruzada, séculos atrás, por outros judeus que também tentaram tecer sua escritura 
no interior tumultuoso da tradição. A consciência do exílio definiu a visão benjaminiana da história (do mesmo modo que sua experiência genebrina e europeia permitiu ao jovem Borges olhar com outros olhos seu passado argentino), essa milenar percepção do desenraizamento, da pátria confinada ao livro, de uma diáspora destinada a atravessar o interminável espaço da história na espera messiânica do dia da redenção. Em Benjamin a escritura é urgência, memória, fidelidade, amparo frente à barbárie que se aproxima, continuidade de uma tradição ameaçada de morte. Borges, de acordo com esta leitura que estamos fazendo, possui outra sensibilidade, seus desenraizamentos têm outras conotações, seu próprio anacronismo aponta para outro sentido. A experiência judaica é demarcatória, indica um peculiar roteiro intelectual; a experiência de Borges responde a desinteligências de época, é gerada por essa conexão, nele tão original, entre o antigo e o presente. A experiência do exílio e da perseguição definem uma escritura, modelam um pensamento. Borges viveu o final de uma época, tratou de ficcionalizar a trama desta história perturbadora, poetizou uma cidade que já não era. Há nele uma escritura da nostalgia que em diversas ocasiões deixa entrever um ceticismo protetor, como se este fosse um paliativo diante do desmoronamento deste mundo cada vez mais ausente da realidade cotidiana, e cuidadosamente guardado na imaginação. Borges sabe que suas incursões pelo território opaco da memória pressupõem perturbar a fonte das lembranças, convertê-las em algo diferente do que haviam sido no distante tempo de sua realização. É o que podemos comprovar em um dos textos-chave da narrativa borgeana - "Tlön, Uqbar, Orbius Tertius" - onde o escritor sublinha que a "metódica elaboração de hrönir [...] prestou serviços prodigiosos aos arqueólogos. Permitiu interrogar e até modificar o passado, que agora não é menos plástico e menos dócil que o porvir". "Modificar o passado" é o que o narrador faz ao desdobrar essa alquimia de recordações obscurecidas pelo passar do tempo e a ressignificação produzida pela ficção. $O$ passado, através desta conjunção, vive um processo de restituição que, como Borges assinalou claramente no texto antes citado, implica uma modificação desse tempo acontecido. Deveríamos acrescentar que a recordação borgeana não possui uma faculdade redentora, um salvar no presente os sofrimentos das gerações anteriores; sua função - se é possível utilizar essa palavra - é fundamentalmente estética.

Benjamin percorre outro caminho. Sua relação com o passado está profundamente trabalhada pelo judaísmo, por esse "romance desesperado dos eternamente desesperançados" (frase escrita por Pursewarden, o personagem de $O$ quarteto de Alexandria, de L. Durrell). Benjamin assume a responsabilidade - muito judaica - de assumir o sofrimento de gerações 
passadas e, também, da tremenda dor da natureza. Sua visão redentora é reparadora e não se projeta como uma escatologia da predestinação; a teologia benjaminiana, como a de Kafka, é negativa. Em seu ensaio sobre Kafka, Benjamin se detém em um estranho texto de Max Brod: "Recordo - diz Brod - um diálogo com Kafka, cujo ponto de partida era a Europa atual e a decadência da humanidade. 'Somos - disse ele - pensamentos nihilistas, pensamentos de suicídios que afloram na mente de Deus'. Isto em princípio me fez pensar na visão de mundo da Gnose: Deus como demiurgo maligno e o mundo como seu pecado original. 'Oh não - disse -, nosso mundo é somente um mal-humor de Deus, um mau dia’. Haveria então esperança fora da manifestação deste mundo que conhecemos? Ele sorriu: 'Sem dúvida, muita esperança, infinita esperança, mas não para nós.” ("Franz Kafka en el décimo aniversario de su muerte"). Visão crepuscular que, no entanto, como a de Benjamin, recolhe o legado da tradição judaica que considera o tempo messiânico como o espaço da conjugação de todas as gerações. Geoffrey Hartman escreveu palavras esclarecedoras que vale a pena citar: "Este quiasma de esperança e catástrofe é o que livra a esperança de ser desmascarada e mostrada unicamente como catástrofe, como a ilusão ou o insatisfeito movimento de desejo que afogaria tudo. A fundação da esperança se converte em reminiscência, o que confirma a função e também o dever do historiador e do crítico. Recordar o passado é um ato político, uma 'busca' que nos envolve em imagens que podem nos constranger a nos identificarmos com elas, e que denunciam o 'débil poder messiânico' hoje corrente (Tese 2). Estas imagens, desgarradas de sua localização fixa na história, desfazem o conceito de um tempo homogêneo e se inserem no presente ou o reconstituem".

Borges se move em outro registro, sua visão da história tem um caráter mitologizante, a-histórico, inclinado fortemente para os arquétipos e, também, para as fixações infantis (é evidente a recorrência, ao longo de sua prolongada vida de escritor, da projeção do rosismo em sua obra; sua leitura do primeiro peronismo, sua experiência prática de opositor ao regime populista, foi mediada pela memória familiar da ditatura de Rosas. Perón, aos olhos de Borges, nada mais foi que a repetição especular de Rosas, a reiteração de uma experiência já vivida). A prosa borgeana, no entanto, está saturada de história, seus personagens sempre ocupam as bordas, permanecem nos umbrais ou se equivocam de lugar. São personagens de um tempo acontecido, incapazes de se adequar às exigências, para eles inverossímeis, do progresso; seus valores já não pertencem ao presente, têm a ver com a coragem, a camaradagem, a palavra empenhada. Um mundo de valores em desuso, anacrônicos, que se desfazem no interior da sociedade burguesa e consumista. 
Através destes personagens das margens de Buenos Aires, destes compadritos do final do século XIX, homens de faca ligeira a serviço da honra e de algum cacique local - porém amparados em um código que não tem nada a ver com a política -, Borges traça a encruzilhada final de uma época e de um mundo (e não seria arriscado dizer que ele toma o partido desses fantasmas do passado, que conseguiu entrever em seus dias de infância). Há em sua escritura uma sorte de vindicação, um intento de redimir essas figuras esquecidas e desprestigiadas, sem contudo alcançar o gesto salvífico do messianismo judaico. Borges, o erudito sensível, o intelectual refinado, empunha a caneta - em algumas de suas melhores páginas - para desenterrar a memória de obscuros personagens de um subúrbio onde a coragem e a bravura ficaram sepultados para sempre. Borges retrata um tempo pré-moderno, esse espaço de metamorfose em que o campo vai se tornando cidade. Com um ar de melancólico ceticismo, Borges desdobra as artes de sua escritura para retratar uma paisagem desvanecida, que apenas a alquimia da ficção e da memória pode nos oferecer.

Benjamin constrói sua obra crítica desde uma perspectiva que tem na história um referente essencial, porém não a história no sentido de uma sucessão linear do tempo, e sim como cenário de profundas transformações que surpreendem o decurso harmônico da sociedade. E o crítico procura descobrir esses pontos de clivagem, esses momentos nos quais a claridade do céu é brutalmente decomposta pela potência do relâmpago. Benjamin mergulha na modernidade, em suas zonas de fundação, não para exaltar a continuidade de um modelo de cultura, mas para entender a trama dialética que nos permite reconhecer a proximidade da decadência ali onde ainda permanece o esplendor.

Borges e Benjamin, duas sensibilidades que se conjugam e que se distanciam, duas experiências exemplares em meio a uma época extraordinária e impiedosa. Nestas páginas simplesmente quisemos nos aproximar de certos pontos em comum, apontar para alguns problemas de interpretação. A nós interessa pôr em evidência a paixão da escritura como afirmação do espírito; ressaltar esse comum anacronismo que os converte em agudos críticos da lógica do progresso e da modernização. Fazer cruzar seus caminhos, estabelecer um diálogo entre eles, implica exercer uma leitura distinta de nosso presente, quiçá a contrapelo; supõe apropriar-nos de uma espiritualidade da qual nos sentimos cada vez mais órfãos. Borges e Benjamin, dois modelos de escritores que determinam nosso olhar contemporâneo, e que seguem nos prometendo a aventura da criação e do pensamento.

Janeiro de 1992. 
